Dario Pozzoli and Marco Ranzani

Participation and Sector Selection in Nicaragua

Department of Economics 


\title{
Participation and Sector Selection in Nicaragua*
}

\author{
Dario Pozzoli ${ }^{\dagger}$ \\ Aarhus School of Business \\ and Aarhus University
}

\author{
Marco Ranzani ${ }^{\ddagger}$ \\ UCSC
}

\begin{abstract}
This paper investigates the structure of the labor market in Nicaragua and is aimed at understanding the determinants of the choice between a number of segments, namely inactivity, unemployment, agriculture, formal and informal sector. In addition, a model with a separate participation equation is estimated: it allows understanding that age is mainly a supply side factor, while education is an important element determining employers' choice. Information networks, captured by the presence of a household member working in the formal sector, and geographical barriers to mobility also play a leading role.
\end{abstract}

JEL Classification: J42, O17, O54.

Keywords: Segmentation, Multisector labor markets, Nicaragua.

\footnotetext{
* The authors thank Pierella Paci for very useful comments on an earlier version of this paper, and the World Bank for providing the data. The World Bank, its Executive Directors and the countries they represent are not responsible of the views expressed in this paper, which involve the sole responsibility of the authors. This work benefits from the findings of a previous study, Making Work Pay in Nicaragua: Employment, Growth, and Poverty Reduction, carried out by one of the authors at his time at the World Bank as part of the program on "Employment and Inclusive Growth" by the Jobs and Migration cluster in the Poverty Reduction and Development Effectiveness Group.

${ }^{\dagger}$ Address: Address: Aarhus School of Business Department of Economics, Frichshuset, Hermodsvej 22. DK-8230 Aabyhoj. E-mail: dpozzoli@asb.dk.

‡ Corresponding Author Address: Universita’ Cattolica - Largo Gemelli, 120123 Milano, Italy. Email: marco.ranzani@virgilio.it. Phone: (+39)3394080901.
} 


\section{Introduction}

Labor market in Nicaragua is typical of low- and middle-income countries: unemployment rate is low (less than 3.5 percent in 2001), informal sector share is large (82 percent of waged workers), as well as that of employment in agriculture (37 percent), there is widespread self-employment and many unpaid individuals working in family enterprises. As explained in Gutierrez et al. (2008), that is a reflection of a country's industrialization level: agriculture is a low-productivity and low-pay sector where many people find a job, most of them as self-employed; they cannot afford unemployment since Nicaragua lacks social safety net which can support job-seekers while looking for a job.

This paper investigates the structure of the labor market in Nicaragua in order to understand the factors affecting the choice between formal, informal sector and agriculture, while taking into account participation decision and unemployment.

We find that age is mainly a supply side factor and education is an important element determining employers' choice. Information networks, captured by the presence of a household member working in the formal sector, and geographical barriers to mobility also play a leading role.

The rest of the paper is structured as follows: section 2 reviews the relevant literature and presents the economic motivation of our econometric model, section 3 describes the data, section 4 specifies the empirical model, section 5 illustrates the results, section 6 discusses the main results and policy relevant implications, section 7 concludes.

\section{Literature review and economic rationale}

The scope of this section is to provide the reader with an overview of the extensive literature on developing countries' labor market with a bias towards works with empirical applications to Nicaragua.

Starting from the theories of dualist development (Roy, 1951 and Lewis, 1954) and of labor market segmentation (Piore, 1979) to end with one of the most recent studies of multiple segments (Fields, 2007), the literature has argued that the hypothesis of 
segmentation might give a more realistic and accurate description of labor markets in developing countries compared to perfect competition.

The idea at the base of the dualistic or multi-sector labor markets view is that there is a number of distinct segments with possibly different earnings functions, and that the access to some jobs in some segments is restricted because the number of individuals looking for such jobs is larger than the number of jobs available. That implies queuing for those jobs, which can take the form of unemployment for individuals who can claim unemployment benefits in urban areas or employment in low-pay agricultural informal sectors for the others.

Pisani and Pagán (2003) investigate whether informal workers queue for formal sector jobs and the behavior of employers who select informal workers from the queue. They find education, urban residence and access to other household income affect the likelihood of formal sector employment. Formal sector employers select informal workers living in cities, more experienced and more educated males and females working in agriculture. Pisani and Pagán (2004) test whether the informal labor market is dynamic using 1993 and 1998 Nicaraguan data. They assume that individuals choose the sector which maximizes utility taking into account human capital, the sector-specific labor market value of human capital, unobserved ability, and the explicit and implicit costs involved in the formal sector employment decision. They use a three-equation switching regression model and find that informal sector workers queue for formal jobs, and that education as well as gender is a primary determinant of formal sector participation.

Gutierrez et al. (2008) devote one chapter to segmentation analysis where they estimate selection corrected earnings equations but do not take into account the decision to participate to the labor market. They adopt two alternative sector groups for the equation aimed at correcting for selection bias: in the first, they use seven worker type categories (non-farm waged workers, employers, self-employed and unpaid workers in both agriculture and outside agriculture); the second alternative includes an industrywise distinction between formal and informal jobs. They find that education is an important determinant of working outside agriculture as well as region of residence; non-labor income strongly affects the likelihood of becoming an employer. 
As explained in the introduction, the Nicaraguan labor market is characterized by low unemployment rate, and high shares of informality and of agricultural employment. The activity rate was 64.39 per cent in 2001, and the unemployment rate less than 4 per cent. The main labor market issue is not how to get people to work but rather how to get people good jobs. What does that mean? Good jobs can be defined as jobs with high returns to education, good pay and working conditions, and therefore jobs which are less likely to be associated with poverty. The good jobs sector does not necessarily coincide with the formal sector, traditionally thought as a free entry sector where people queue for a formal job, since workers might value the flexibility which may be associated to an informal job, and non-monetary incentives other than monetary benefits.

In such a context, we think there is a need for understanding what makes individuals prefer one sector to another, eventually taking into account the participation decision which regards mainly females and urban individuals. That is due to the fact that women are often in charge of children's care, whereas people living in urban areas are more likely to afford education and do not own land which can be cultivated and therefore often times it is source of low-pay employment for entire households.

We model the choice of a labor market sector as a contemporaneous decision via a multinomial probit which fits better the constraints faced by any individual in the labor market. In other words, each individual decides whether to participate or not to the labor market, though this is often not a choice for members of poor households, and then decides the sector to work in. The multinomial probit does not rely - unlike other models - on the independence of irrelevant alternatives assumption which might be excessively binding, and the inclusion of a participation equation allows disentangling partially labor supply and labor demand determinants of the choice. We propose a more comprehensive and less assumption-constrained analysis compared to previous studies. 


\section{Data}

The data set comes from the 2001 Nicaragua National Household Living Standards Survey ${ }^{4}$ which provides individual and household level socio-economic data for 4,191 households. The unit of observation for family relationships, education, health, economic activity, and time use sections is the individual; for housing, consumption, household enterprise, and agro-pastoral activities is the household.

Informal sector is defined according to enrolment in the social security system: every worker who does not pay social security contributions is considered an informal worker regardless of the industry he works in.

We retain individuals between 6 and 64 years of age, individuals who do answer the question concerning payment of social security contributions, whose sector of economic activity and employment category can be identified, and we exclude non-household relatives.

Descriptive statistics by gender give interesting insights about the characteristics of the Nicaraguan labor market (Table 1a and 1b). ${ }^{5}$ Inactive and unemployed are younger than working individuals, more educated persons are employed in the formal sector, or they are unemployed, the share of formal workers is much larger in households with a member working in the formal sector, and the share of females working and inactive changes according to the birth of a child while males' choices are less affected. Nonlabor income, which includes imputed rent, transfers for education, received food gifts and remittances, charities, returns from capital and pensions, is slightly higher among working females than among females non-participating to the labor market, whereas it is higher for inactive and unemployed men. Individuals who live in a household running its own business end up working in agriculture or informally outside agriculture; unemployed and inactive are concentrated in urban areas, as well as non-agricultural employment. Managua, the region of the capital city, attracts formal and informal workers.

\footnotetext{
${ }^{4}$ Encuesta Nacional de Hogares sobre Medicion de Niveles de Vida (EMNV), conducted by INEC, the National Statistics and Census Institute. For further information, www.worldbank.org/lsms.

${ }^{5}$ We take account of the survey design used for the Living Standards Measurement Survey, which involved stratified sampling by urban/rural areas.
} 


\section{Empirical methodology}

In this section we put forward the multinomial probit model which is useful for the purpose outlined in the introduction. We begin with a basic model and subsequently introduce additional features.

Assume that an individual $i$ perceives utility $U_{i j}$ if she chooses sector $j$ and that this utility obeys:

$$
U_{i j}=X_{i j}^{\prime} \beta+\varepsilon_{i j}
$$

where $X_{i j}$ is a $k$-dimensional vector of explanatory variables, $\beta$ is a $k$-dimensional parameters vector, and $\varepsilon_{i j}$ is an unobserved random variable, $i=1, \ldots \ldots, N$ and $j=1, \ldots \ldots, J$. In our empirical analysis, we consider two different models: the first includes four different sectors, inactivity, unemployment, formal employment, informal employment; the second model augments the first adding agriculture to the previous four sectors. The unknown parameters vector $\beta$ describes the effect of explanatory variables $X_{i j}$ on the utilities. There are two main factors determining the choice of the working sector. One is rationing, meaning the existing constrained demand for labor. The second is individual preference, meaning what the individual would choose in the absence of rationing. We cannot assume that rationing and preference have two separate sets of determinants since each factor can be interpreted as reflecting both labor supply and labor demand. For example, on the demand side, skills, education, and experience are employers' screening elements, whereas location reflects local economic and labor market conditions. On the other side, workers' preferences change with age and household characteristics, and they are affected by individuals' expected returns from labor, which in turn change according to skills, experience, etc. The combination of rationing and preferences determines the selection of the sector observed in the data.

Thus we have an individual $i$ who chooses sector $j$ if the perceived utility of sector $j$ exceeds the perceived utilities of all the other sectors, that is, if

$$
U_{i j}>U_{i m} \quad \text { for } \quad m=1, \ldots ., j-1, j+1, \ldots . ., J
$$


As the random terms are not observed, we do not observe the perceived utilities $U_{i j}$. In fact, we observe only the actual sector chosen. Define the variable $d_{i}=j$ if individual $i$ chooses sector $j$. Given equation (2), the probability $\operatorname{Pr}\left(d_{i}=j\right)$ is equal to:

$$
\operatorname{Pr}\left(d_{i}=j\right)=\operatorname{Pr}\left(U_{i j}>U_{i 1}, \ldots \ldots, U_{i j}>U_{i J}\right)
$$

This probability depends on the assumptions about the distribution of $\varepsilon_{i j}$. If we take for $\varepsilon_{i j}$ an independent, uncorrelated type-1 extreme value distribution, we obtain the multinomial logit model of McFadden (1973). This model assumes independence of irrelevant alternatives. To avoid this assumption, we assume that the $J$-dimensional disturbance vector $\varepsilon_{i}=\left(\varepsilon_{i 1}, \ldots \ldots, \varepsilon_{i J}\right)$ is normally distributed, that is,

$$
\varepsilon_{i} \sim \operatorname{NID}(0, \Sigma)
$$

where $\Sigma$ is a $(\mathrm{J} \times \mathrm{J})$ covariance matrix. This leads to a multinomial probit (MNP) model: see Hausman and Wise (1978), among others.

As sector choice is fully determined by utility differences (see equation 2), it is conventional to measure utility relative to the alternative $\mathrm{J}$ to indentify the model parameters. Thus, we can define

$$
\begin{array}{r}
\quad U_{i j}-U_{i J}=X_{i j}^{\prime} \beta-X_{i J}^{\prime} \beta+\varepsilon_{i j}-\varepsilon_{i J} \\
\tilde{U}_{i j}=\tilde{X}_{i j}^{\prime} \beta+\widetilde{\varepsilon}_{i j} \quad \text { for } \quad j=1, \ldots . . J-1
\end{array}
$$

where $\tilde{U}_{i j}$ denotes the perceived relative utility of sector $\mathrm{j}$, that is, relative to sector $\mathrm{J}$. Hence, individual $\mathrm{i}$ chooses sector $\mathrm{j}$ if $\tilde{U}_{i j}$ is the maximum of the relative utilities unless all relative utilities are smaller than zero, which corresponds to choosing sector J. Of course, the relative utility of sector $\mathrm{J}$ is zero.

We also estimate the sector choice equation excluding inactivity as an alternative in order to allow for sample selection due to the decision to participate to the labor market. 
In this case, we augment equation (4) with a probit equation for the probability of being active in the labor market:

$$
a^{*}{ }_{i}=Z_{i}^{\prime} \gamma+u_{i}
$$

where $a^{*}{ }_{i}$ is a continuous latent propensity to be active on the labor market, $\mathrm{Z}_{\mathrm{i}}$ is a vector of observables that may overlap with $X_{i}$ and $u_{i}$ is an error term distributed as standard normal. We decide to estimate (4) and (5) using a generalization of the two step selection bias correction method introduced by Heckman (1979). A consistent estimator of $\beta$ is obtained by estimating equation (4) where along with the covariates $\mathrm{X}$ we add the following correction terms:

$$
\lambda_{i j}=\frac{\exp \left(-0.5\left(Z_{i}^{\prime} \gamma\right)^{2}\right)}{\sqrt{2 \pi \Phi\left(Z_{i}^{\prime} \gamma\right)}}
$$

The estimation of the equation of interest (4) is thus implemented by first estimating the $\gamma$ 's in order to obtain the selection adjustment terms, and then by including them into the sector choice equation to consistently estimate $\beta$ via maximum likelihood.

An economic identification of this model requires the availability of a valid instrument, i.e. a variable that can be deemed only to affect the participation decision with no direct effect on the choice of the working sector after participation to the labor market has been controlled for. The data contains an excluded variable which might affect the decision to participate to the labor market, and conditional on $X^{\prime}$, be excluded from the sector choice equation: the presence in the household of a child who is 1 year old or younger. The presence of a baby, in need of cares from his/her mother, is expected to strongly affect the participation decision of the mother herself as well as of any other working age member of the household as a consequence to her decision or as a contemporaneous intra-household bargaining. 


\section{Results}

We will first discuss the results about the choice of the segment including inactive and unemployed among the available alternatives, and then we will present the findings of the model with the participation equation.

The first alternative consists of four sectors: inactivity (the base category), unemployment, formal employment, informal employment. Regressions have been run separately for males and females (table 2). The second degree polynomial in age has the expected sign, namely the linear term enters positively and the quadratic term negatively: thus age increases, at a decreasing rate, the probability of being unemployed or of working in either the formal or the informal sector as compared to being inactive for both males and females. Education increases the probability of being unemployed (since unemployed are mostly ex-formal waged workers who get unemployment benefit) or a formal worker, while high education (secondary/tertiary) decreases the probability of working in the informal sector for males. Having a young child increases the likelihood of working or of being unemployed for males relative to inactivity since a bigger household has larger consumption needs, while it lowers females' probability of working since they take care of the new born. As expected, a household member working in the formal sector acts as an information network by making higher the probability of working in the same sector (for men), while lowering that of being informal (for both men and women). Living in a high-income household allows individuals to be inactive because they can afford it, whereas living in a household which owns a business has the opposite effect. Since waged jobs are more common in big cities and they are the only way to benefit from an unemployment subsidy, the dummy for urban areas increases the likelihood of unemployment (for both males and females), and of working in either the formal or the informal segment for females only. Regional dummy variables, which controls for local labor market conditions, confirm that in Managua the probability of being unemployed compared to inactive is higher, as well as the probability of being a formal worker; the opposite holds for informal workers.

The second combination of segments allows for agriculture in addition to the previously defined sectors (table 3). Agriculture employs 20 per cent of Nicaraguan workers, and 
since almost all of them are informal, we do not introduce a formal/informal sub sector within it. Given that the effect of each factor commented above holds in the new model, we limit the discussion to the new segment. Age has a positive impact on the probability of working in agriculture compared to being inactive, while having some education lowers it for males and it turn out not significant for females. Having a baby has a positive effect on the likelihood of working in agriculture for males and a negative one for females, as explained above. The network effect of formal workers does not work for agriculture since it is almost completely informal, and living in a household running its own business increases the chance of working in the primary sector, the opposite effect derives from living in urban areas and from being from a rich household.

The second set of estimates includes the same group of segments of the first model but separately allows for a participation equation. Thus, multinomial probit estimates are net of the participation decision' effect, and the effect of unobservables in the selection equation, which are related to the choice of a segment, is captured by the inverse Mills ratio coefficient. Workers preferences determining the choice between participation and non-participation are taken into account in the first step, and thereafter the choice of a segment takes place.

Estimates of the participation equation are shown in table 4: age plays a positive role, though the positive effect lowers as individuals age; education has a positive effect for females but it is not statistically significant for males; non-labor income increases the probability of being inactive, while living in a household running an enterprise lowers it. The presence of a baby keeps its differential effect on males and females decisions: in the first case it makes the participation probability higher, and it decreases it in the latter. Having a member of the household working in the formal sector, that had a network effect in the previous model, turns now negative in the first step, and it might be interpreted as a disincentive effect, whereby individuals from households with a formal worker feel less the need of getting a job since formal sector workers have high labor earnings and in case they loose their job, they can benefit from unemployment subsidies.

Turning now to the choice of a specific labor market segment, the first alternative is among unemployment, formal and informal sector (table 5). Age has the usual effect only on unemployment for males, and it does not affect the relative probability of 
working in the formal sector after the selection process has been corrected for. Education instead maintains its effect: being educated compared to having no schooling makes the probability of working in the formal sector and of being unemployed higher than being informal. The positive sign attached to education dummies is likely to be due to the composition of the unemployment pool: as mentioned above, unemployed are mainly waged workers who lost their job. A household running a family business, which is usually an informal activity, lowers the chance of unemployment and formal job compared to an informal one. Having a household member working in the formal sector confirms its positive effect on the probability of getting a formal job, even after the selection equation, thus pointing to the strength of information networks in the Nicaraguan labor market as found for the maquilla ${ }^{6}$ sector in Gutierrez et al. (2008). It also has a positive effect on the likelihood of unemployment relative to that of being an informal worker for females. Once women decide to participate, a formal worker in the family works as a buffer by allowing them to be unemployed and waiting for a formal job. Non-labor income has basically no effect except for males working in the formal sector. Residence in regions other than the capital city's region (Managua) has a negative impact on the likelihood of getting a formal job, or of being unemployed relative to getting an informal job since waged formal jobs and, as a consequence, unemployed are concentrated in that region. The selection term is positive for males unemployed and negative for females in the formal sector: unobservables in the participation equation are negatively correlated with the unemployment probability for males and positively with the probability of being a formal worker for females.

The second set of choices includes unemployment, agriculture, the formal and the informal sector (table 6). After estimating the participation equation, age maintain its significance only for women unemployed or employed in agriculture, and in this last case, age decreases the probability of getting a job at an increasing rate. Education obviously lowers the likelihood of being employed in agriculture relative to being in the informal sector, while it increases the probability of working in the formal sector or of being unemployed (for females). A formal worker in the household positively affects the probability of getting a job in the formal sector, and living in a household with a

\footnotetext{
${ }^{6}$ The maquilla sector includes all production units located in the 'Special Export Processing Zones'. Production is undertaken with mostly imported materials using local labor and all output is destined to export markets.
} 
family business reduces the chance of getting a formal job. Variables for location of residence have the expected sign. Finally, the selection term is statistically significant for both males and females on the probability of being formal, while it turns out significant only for female in the other two segments. Also its sign is different across sectors: it is negative on the probability of employment, be it either agriculture or formal, and positive on the probability of unemployment.

\section{Predicted probabilities and policy implications}

Table 7 and 8 illustrate predicted probabilities from the first model (without a participation equation) for average types of individuals. Education increases the probability of getting a job in either the formal or the informal sector, or of unemployment, while it reduces the probability of being inactive or employed in agriculture for both females and males. Striking is the effect of tertiary education on the likelihood of being a formal or an informal worker: the effect is strong not only at young ages, but also for older individuals. The amount of per capita non-labor income does not change much the probability of being employed in each sector, but it increases the chances of being inactive, especially for young females.

Figures 1 and 2 show, separately for women and men, how the probability of ending up in each segment changes according to age. The risk of inactivity is initially very high since a small share of young individuals work (the working sample includes people between 6 and 64 years of age), and it decreases with age up to the age of retirement from the labor force when it surges again to 60 per cent. The risk of unemployment is very low along the entire age distribution for both sexes; the probability of being employed in the formal sector increases with age and reaches its maximum at around 40 years of age, and it is lower than the probability of being employed in agriculture or in the non-farm informal sector.

The analysis presented here has some policy implications which can help designing policies so that individuals are able to access what has been called 'the most preferred sector' in Gutierrez et al. (2008), or in other words non-farm jobs. The two different models, with and without a selection equation, allow disentangling partially the effect of supply side from demand side factors. Indeed, the participation equation capture the effect of supply side factors on the probability of participation to the labor market, thus 
netting out subsequent estimate of sector choice from them. It turns out that age is a significant determinant of individuals' decisions to participate, whereas education is significant only for females. Taking into account these effects, the estimates of the segment choice equations show that age is not a crucial factor of segment choice unlike education. Thus, workers take decisions according, among other things, to their age, but that is not the case for employers since age is no more significant after the selection is carried on. Education, precisely high education (secondary and tertiary) is a decisive element which clearly marks out individuals in good and bad jobs. This finding does not only hold for young individuals who enter the labor market for the first time, but also for people next to retirement (as shown by the predicted probabilities). Location of residence is a further element which determines the sector where individuals end up working, thus pointing to geographical barriers to mobility which can preclude individuals born in geographically ‘unlucky’ areas from accessing good jobs.

An effective policy tool would rely on increasing educational attainments in order to provide individuals with the most important tool to get out of bad jobs as long as labor demand will be able to absorb a higher-educated labor force. As to geographical mobility, it is not clear from the analysis whether workers are limited by lack of infrastructures rather than by their aversion to geographical movements. On the other side, it emerges quite clearly how most of the formal non-farm jobs are concentrated in urban areas of Managua region where manufacturing and public sector find their preferred location. If that is the case, the economic development of other regions could also help creating good jobs closer to 'low-mobile' individuals.

\section{Concluding remarks}

We analyze factors determining individuals' condition in the Nicaraguan labor market: participating to the labor market, working either in the formal or informal sector, and working in agriculture or in non-agriculture. The analysis considers both the choice of the sector as contemporaneous to the participation decision and as subsequent to it.

Using 2001 wave of Nicaragua Living Standards Measurement Survey, we find that education is the most important factor for the choice between formality, informality and agriculture. We show that information networks, captured by the presence of a 
household member working in the formal sector, have an effect on the relative probability of working in a sector rather than in another, and mobility barriers, as captured by the differential and significant effect of urban and regional dummies, are a decisive factor affecting the choice of a segment.

Increasing education of the working age population as well as development of non-farm job opportunities in regions other than Managua could give workers more chances of getting good jobs. As to agriculture which is the bad job sector, as found in other studies, policies aimed at increasing its productivity are likely to be the most effective tool to get households and individuals employed there out of poverty and of low-paying jobs. 


\section{References}

Fields, G. (2007) “A Guide to Multisector Labor Market Models”, Paper Prepared for the World Bank Labor Market Conference, Washington, D.C. November 18-19 November, 2004.

Fields, G. (2006) "Employment in Low-Income Countries beyond Labor Market Segmentation?", Document prepared for the World Bank conference "Rethinking the Role of Jobs for Shared Growth,” Washington D.C., June 19, 2006.

Gutierrez, C., Paci, P. and Ranzani, M. (2008) Making Work Pay in Nicaragua: Employment, Growth, and Poverty Reduction, The World Bank, Washington, D.C.

Hausman, A.J. and Wise, D.A. (1978) “A Conditional Probit Model for Qualitative Choice: Discrete Decisions Recognizing Interdependence and Heterogeneous Preferences”, Econometrica, Vol. 46(2): 403-426.

Heckman, J.J. (1979) “Sample Selection Bias as a Specification Error”, Econometrica, Vol. 47(1): 153-162.

Lewis, W. A. (1954) "Economic Development with Unlimited Supplies of Labour," Manchester School, 22: 139-191.

Maddala, G.S. (1983) Limited-Dependent and Qualitative Variables in Econometrics, Cambridge University Press.

McFadden, D. (1973) "Conditional Logit Analysis of Qualitative Choice Behavior," in Frontiers of Econometrics, ed. P. Zarembka, New York: Academic Press, pp. 105-142.

Perry, G.E., Maloney, W.F., Arias, O.S., Fajnzylber, P., Mason, A.D., SaavedraChanduvi, J. (2007) Informality: Exit and Exclusion, The World Bank, Washington, D.C.

Piore, M. J. (1983) "Labor Market Segmentation: To What Paradigm Does It Belong?," American Economic Review Proceedings, May 1983, 73, 249-53.

Pisani M.J. and Pagàn J.A. (2003) "Sectoral Queuing in a Transitional Economy: The Case of Nicaragua in the 1990s”, Labour, 17, 571-97.

Pisani M.J. and Pagàn J.A. (2004) "Sectoral Selection and Informality: a Nicaraguan Case Study”, Review of Development Economics, 8, 541-56.

Roy, A.D. (1951) “Some Thoughts on the Distribution of Earnings,” Oxford Economic Papers, 3: 135-146. 
Table 1a: Summary Statistics (Females).

\begin{tabular}{|c|c|c|c|c|c|c|c|c|c|c|}
\hline \multirow{2}{*}{$\begin{array}{l}\text { Females } \\
\text { Variable }\end{array}$} & \multicolumn{2}{|c|}{ Inactive } & \multicolumn{2}{|c|}{ Unemployed } & \multicolumn{2}{|c|}{$\begin{array}{l}\text { Employed in } \\
\text { agriculture }\end{array}$} & \multicolumn{2}{|c|}{$\begin{array}{l}\text { Employed in the } \\
\text { formal sector }\end{array}$} & \multicolumn{2}{|c|}{$\begin{array}{l}\text { Employed in the } \\
\text { informal sector }\end{array}$} \\
\hline & Mean & Std. Dev. & Mean & Std. Dev. & Mean & Std. Dev. & Mean & Std. Dev. & Mean & Std. Dev. \\
\hline Age & 21.764 & 14.761 & 25.766 & 9.271 & 29.518 & 14.289 & 33.739 & 9.836 & 33.936 & 13.054 \\
\hline No schooling & 0.242 & 0.428 & 0.081 & 0.274 & 0.262 & 0.442 & 0.015 & 0.121 & 0.148 & 0.355 \\
\hline Incomplete primary & 0.398 & 0.490 & 0.121 & 0.327 & 0.469 & 0.501 & 0.109 & 0.312 & 0.287 & 0.452 \\
\hline Primary/Incomplete Secondary & 0.265 & 0.441 & 0.401 & 0.492 & 0.224 & 0.419 & 0.239 & 0.427 & 0.376 & 0.485 \\
\hline Secondary/Tertiary & 0.095 & 0.293 & 0.397 & 0.491 & 0.046 & 0.210 & 0.637 & 0.481 & 0.189 & 0.391 \\
\hline Presence of a child (less than 1 year old) in the household & 0.275 & 0.447 & 0.267 & 0.444 & 0.180 & 0.386 & 0.157 & 0.364 & 0.208 & 0.406 \\
\hline Non-labor income divided by household size & 3.226 & 11.303 & 3.809 & 5.106 & 2.014 & 2.712 & 6.970 & 11.982 & 4.353 & 7.527 \\
\hline A member of the household working in the formal sector & 0.219 & 0.414 & 0.280 & 0.451 & 0.114 & 0.319 & 0.411 & 0.493 & 0.203 & 0.403 \\
\hline Household running an enterprise & 0.111 & 0.314 & 0.092 & 0.290 & 0.519 & 0.502 & 0.107 & 0.309 & 0.374 & 0.484 \\
\hline Living in an urban area & 0.555 & 0.497 & 0.762 & 0.428 & 0.305 & 0.462 & 0.891 & 0.312 & 0.788 & 0.409 \\
\hline \multicolumn{11}{|l|}{ Region Dummies } \\
\hline Region1 (Managua) & 0.237 & 0.425 & 0.406 & 0.493 & 0.057 & 0.233 & 0.507 & 0.501 & 0.310 & 0.463 \\
\hline Region2 (Pacific) & 0.303 & 0.459 & 0.309 & 0.464 & 0.418 & 0.495 & 0.256 & 0.437 & 0.373 & 0.484 \\
\hline Region3 (Central) & 0.332 & 0.471 & 0.215 & 0.412 & 0.434 & 0.498 & 0.175 & 0.380 & 0.238 & 0.426 \\
\hline Region4 (Atlantic) & 0.129 & 0.335 & 0.070 & 0.256 & 0.091 & 0.289 & 0.063 & 0.244 & 0.079 & 0.269 \\
\hline Observations & \multicolumn{2}{|c|}{6,333} & \multicolumn{2}{|c|}{120} & \multicolumn{2}{|c|}{119} & \multicolumn{2}{|c|}{453} & \multicolumn{2}{|c|}{1,791} \\
\hline
\end{tabular}


Table 1b: Summary Statistics (Males).

\begin{tabular}{|c|c|c|c|c|c|c|c|c|c|c|}
\hline \multirow{2}{*}{$\begin{array}{l}\text { Males } \\
\text { Variable }\end{array}$} & \multicolumn{2}{|c|}{ Inactive } & \multicolumn{2}{|c|}{ Unemployed } & \multicolumn{2}{|c|}{$\begin{array}{c}\text { Employed in } \\
\text { agriculture }\end{array}$} & \multicolumn{2}{|c|}{$\begin{array}{l}\text { Employed in the } \\
\text { formal sector }\end{array}$} & \multicolumn{2}{|c|}{$\begin{array}{l}\text { Employed in the } \\
\text { informal sector }\end{array}$} \\
\hline & Mean & Std. Dev. & Mean & Std. Dev. & Mean & Std. Dev. & Mean & Std. Dev. & Mean & Std. Dev \\
\hline Age & 14.532 & 10.839 & 29.116 & 12.256 & 30.703 & 13.943 & 34.901 & 11.319 & 31.702 & 13.166 \\
\hline No schooling & 0.216 & 0.411 & 0.065 & 0.248 & 0.337 & 0.473 & 0.040 & 0.197 & 0.104 & 0.305 \\
\hline Incomplete primary & 0.456 & 0.498 & 0.219 & 0.414 & 0.431 & 0.495 & 0.139 & 0.346 & 0.300 & 0.459 \\
\hline Primary/Incomplete Secondary & 0.234 & 0.423 & 0.490 & 0.501 & 0.189 & 0.392 & 0.408 & 0.492 & 0.440 & 0.497 \\
\hline Secondary/Tertiary & 0.095 & 0.293 & 0.226 & 0.420 & 0.043 & 0.203 & 0.413 & 0.493 & 0.156 & 0.363 \\
\hline Presence of a child (less than 1 year old) in the household & 0.208 & 0.406 & 0.223 & 0.418 & 0.311 & 0.463 & 0.217 & 0.413 & 0.223 & 0.416 \\
\hline Non-labor income divided by household size & 2.986 & 14.204 & 6.181 & 9.969 & 2.617 & 4.378 & 7.794 & 16.727 & 5.029 & 10.035 \\
\hline A member of the household working in the formal sector & 0.252 & 0.434 & 0.297 & 0.458 & 0.069 & 0.254 & 0.419 & 0.494 & 0.190 & 0.392 \\
\hline Household running an enterprise & 0.132 & 0.338 & 0.126 & 0.333 & 0.307 & 0.461 & 0.109 & 0.312 & 0.282 & 0.450 \\
\hline Living in an urban area & 0.640 & 0.480 & 0.816 & 0.388 & 0.386 & 0.487 & 0.876 & 0.330 & 0.822 & 0.382 \\
\hline \multicolumn{11}{|l|}{ Region Dummies } \\
\hline Region1 (Managua) & 0.294 & 0.456 & 0.403 & 0.492 & 0.084 & 0.278 & 0.549 & 0.498 & 0.341 & 0.474 \\
\hline Region2 (Pacific) & 0.326 & 0.469 & 0.366 & 0.483 & 0.345 & 0.476 & 0.275 & 0.447 & 0.353 & 0.478 \\
\hline Region3 (Central) & 0.261 & 0.439 & 0.173 & 0.379 & 0.467 & 0.499 & 0.132 & 0.339 & 0.224 & 0.417 \\
\hline Region4 (Atlantic) & 0.119 & 0.324 & 0.059 & 0.235 & 0.104 & 0.305 & 0.044 & 0.204 & 0.082 & 0.275 \\
\hline Observations & \multicolumn{2}{|c|}{3,377} & \multicolumn{2}{|c|}{177} & \multicolumn{2}{|c|}{922} & \multicolumn{2}{|c|}{532} & \multicolumn{2}{|c|}{1,786} \\
\hline
\end{tabular}


Table 2: Sector choice (multinomial probit model).

\begin{tabular}{|c|c|c|c|c|c|c|}
\hline & \multicolumn{2}{|c|}{ Unemployed } & \multicolumn{2}{|c|}{ Employed in the formal sector } & \multicolumn{2}{|c|}{ Employed in the informal sector } \\
\hline & men & women & men & women & men & women \\
\hline \multirow[t]{2}{*}{ Age } & $0.31 * * *$ & $0.17 * * *$ & $0.42 * * *$ & $0.30 * * *$ & $0.39 * * *$ & $0.22 * * *$ \\
\hline & $(0.02)$ & $(0.02)$ & $(0.02)$ & $(0.02)$ & $(0.01)$ & $(0.01)$ \\
\hline \multirow[t]{2}{*}{ Age squared/100 } & $--0.39 * * *$ & $--0.24 * * *$ & $--0.51^{* * *}$ & $--0.37 * * *$ & $--0.48 * * *$ & $--0.26 * * *$ \\
\hline & $(0.03)$ & $(0.04)$ & $(0.02)$ & $(0.03)$ & $(0.02)$ & $(0.01)$ \\
\hline \multirow[t]{2}{*}{ Incomplete primary } & 0.21 & 0.09 & 0.31 & $1.02 * * *$ & 0.02 & $0.41^{* * *}$ \\
\hline & $(0.21)$ & $(0.22)$ & $(0.22)$ & $(0.24)$ & $(0.11)$ & $(0.12)$ \\
\hline \multirow[t]{2}{*}{ Primary/incomplete secondary } & $0.38 *$ & $0.64 * * *$ & $0.62 * * *$ & $1.47 * * *$ & --0.18 & $0.62 * * *$ \\
\hline & $(0.20)$ & $(0.21)$ & $(0.22)$ & $(0.20)$ & $(0.12)$ & $(0.13)$ \\
\hline \multirow[t]{2}{*}{ Secondary/tertiary } & 0.19 & $1.32 * * *$ & $0.89 * * *$ & $2.77 * * *$ & $--0.64 * * *$ & $0.91 * * *$ \\
\hline & $(0.22)$ & $(0.23)$ & $(0.27)$ & $(0.20)$ & $(0.17)$ & $(0.18)$ \\
\hline \multirow[t]{2}{*}{ Presence of a child in the household } & $0.25^{*}$ & 0.00 & $0.43^{* * *}$ & $--0.24 *$ & $0.26^{* * *}$ & $--0.17 * *$ \\
\hline & $(0.13)$ & $(0.12)$ & $(0.13)$ & $(0.12)$ & $(0.10)$ & $(0.08)$ \\
\hline \multirow[t]{2}{*}{ A member of the household in the formal sector } & --0.01 & --0.16 & $0.35^{* * *}$ & 0.12 & $--0.43 * * *$ & $--0.33 * * *$ \\
\hline & $(0.14)$ & $(0.13)$ & $(0.11)$ & $(0.13)$ & $(0.10)$ & $(0.08)$ \\
\hline \multirow[t]{2}{*}{ Household with a family enterprise } & $0.46^{* * *}$ & $0.30 * *$ & $0.41^{* * *}$ & $0.57^{* * *}$ & $1.25^{* * *}$ & $1.63^{* * *}$ \\
\hline & $(0.15)$ & $(0.15)$ & $(0.14)$ & $(0.15)$ & $(0.09)$ & $(0.10)$ \\
\hline \multirow[t]{2}{*}{ Living in a urban area } & $0.23^{*}$ & $0.25 *$ & 0.18 & $0.50 * * *$ & 0.09 & $0.65^{* * *}$ \\
\hline & $(0.13)$ & $(0.13)$ & $(0.15)$ & $(0.12)$ & $(0.09)$ & $(0.08)$ \\
\hline \multirow[t]{2}{*}{ Non-labor income } & --0.00 & $--0.01^{*}$ & $--0.01 * *$ & $--0.01^{* *}$ & $--0.00^{*}$ & $--0.01 * *$ \\
\hline & $(0.00)$ & $(0.01)$ & $(0.00)$ & $(0.01)$ & $(0.00)$ & $(0.01)$ \\
\hline \multirow[t]{2}{*}{ Region2 (Pacific) } & 0.12 & --0.06 & --0.19 & $--0.24 * *$ & $0.20 *$ & $0.19 * *$ \\
\hline & $(0.12)$ & $(0.16)$ & $(0.12)$ & $(0.11)$ & $(0.11)$ & $(0.09)$ \\
\hline \multirow[t]{2}{*}{ Region3 (Central) } & --0.04 & $--0.32 *$ & $--0.41 * * *$ & $--0.50 * * *$ & $0.35^{* * *}$ & --0.15 \\
\hline & $(0.15)$ & $(0.18)$ & $(0.13)$ & $(0.12)$ & $(0.11)$ & $(0.09)$ \\
\hline \multirow[t]{2}{*}{ Region4 (Atlantic) } & --0.28 & --0.28 & $--0.71 * * *$ & $--0.36 * *$ & 0.05 & --0.19 \\
\hline & $(0.20)$ & $(0.21)$ & $(0.18)$ & $(0.16)$ & $(0.13)$ & $(0.12)$ \\
\hline
\end{tabular}

Notes: The base outcome is "Inactive”. *** indicates significance at $1 \%$ level, ** at $5 \%$ level; * at $10 \%$ level. Standard errors reported in parenthesis. 
Table 3: Sector choice with agriculture (multinomial probit model).

\begin{tabular}{|c|c|c|c|c|c|c|c|c|}
\hline & \multicolumn{2}{|c|}{ Unemployed } & \multicolumn{2}{|c|}{ Employed in agriculture } & \multicolumn{2}{|c|}{ Employed in the formal sector } & \multicolumn{2}{|c|}{ Employed in the informal sector } \\
\hline & men & women & men & women & men & women & men & women \\
\hline Age & $\begin{array}{l}0.37 * * * \\
(0.02)\end{array}$ & $\begin{array}{l}0.15^{* * *} \\
(0.02)\end{array}$ & $\begin{array}{l}0.42 * * * \\
(0.02)\end{array}$ & $\begin{array}{l}0.31 * * * \\
(0.02)\end{array}$ & $\begin{array}{l}0.37 * * * \\
(0.01)\end{array}$ & $\begin{array}{c}0.23 * * * \\
(0.01)\end{array}$ & $\begin{array}{l}0.31 * * * \\
(0.02)\end{array}$ & $\begin{array}{l}0.17 * * * \\
(0.02)\end{array}$ \\
\hline Age squared/100 & $\begin{array}{c}--0.46^{* * *} \\
(0.02)\end{array}$ & $\begin{array}{c}--0.19 * * * \\
(0.03)\end{array}$ & $\begin{array}{c}--0.51^{* * *} \\
(0.03)\end{array}$ & $\begin{array}{c}-0.38 * * * \\
(0.03)\end{array}$ & $\begin{array}{c}--0.45^{* * *} \\
(0.02)\end{array}$ & $\begin{array}{c}--0.26 * * * \\
(0.02)\end{array}$ & $\begin{array}{c}--0.38 * * * \\
(0.03)\end{array}$ & $\begin{array}{c}--0.24^{* * *} \\
(0.04)\end{array}$ \\
\hline Incomplete primary & $\begin{array}{c}--0.20^{*} \\
(0.12)\end{array}$ & $\begin{array}{r}0.22 \\
(0.16)\end{array}$ & $\begin{array}{c}0.40^{*} \\
(0.24)\end{array}$ & $\begin{array}{l}1.07 * * * \\
(0.26)\end{array}$ & $\begin{array}{c}0.35^{* * *} \\
(0.12)\end{array}$ & $\begin{array}{l}0.42^{* * *} \\
(0.12)\end{array}$ & $\begin{array}{r}0.22 \\
(0.21)\end{array}$ & $\begin{array}{r}0.09 \\
(0.22)\end{array}$ \\
\hline Primary/incomplete secondary & $\begin{array}{c}--0.80 * * * \\
(0.14)\end{array}$ & $\begin{array}{r}0.15 \\
(0.17)\end{array}$ & $\begin{array}{l}0.79 * * * \\
(0.23)\end{array}$ & $\begin{array}{l}1.50^{* * *} \\
(0.21)\end{array}$ & $\begin{array}{l}0.32 * * \\
(0.13)\end{array}$ & $\begin{array}{l}0.66^{* * *} \\
(0.13)\end{array}$ & $\begin{array}{l}0.39 * * \\
(0.19)\end{array}$ & $\begin{array}{l}0.64^{* * *} \\
(0.21)\end{array}$ \\
\hline Secondary/tertiary & $\begin{array}{c}-1.18^{* * *} \\
(0.26)\end{array}$ & $\begin{array}{r}0.26 \\
(0.28)\end{array}$ & $\begin{array}{l}1.03^{* * *} \\
(0.29)\end{array}$ & $\begin{array}{l}2.84^{* * *} \\
(0.21)\end{array}$ & $\begin{array}{l}--0.12 \\
(0.16)\end{array}$ & $\begin{array}{l}0.95^{* * *} \\
(0.18)\end{array}$ & $\begin{array}{r}0.18 \\
(0.21)\end{array}$ & $\begin{array}{l}1.32 * * * \\
(0.23)\end{array}$ \\
\hline Presence of a child in the household & $\begin{array}{l}0.34^{* * *} \\
(0.09)\end{array}$ & $\begin{array}{c}--0.42^{* * *} \\
(0.16)\end{array}$ & $\begin{array}{l}0.36^{* * *} \\
(0.13)\end{array}$ & $\begin{array}{c}--0.25^{*} \\
(0.13)\end{array}$ & $\begin{array}{l}0.23^{* *} \\
(0.10)\end{array}$ & $\begin{array}{c}--0.15^{*} \\
(0.08)\end{array}$ & $\begin{array}{l}0.24 * \\
(0.13)\end{array}$ & $\begin{array}{r}0.00 \\
(0.12)\end{array}$ \\
\hline A member of the household in the formal sector & $\begin{array}{c}--0.58^{* * *} \\
(0.14)\end{array}$ & $\begin{array}{l}--0.13 \\
(0.21)\end{array}$ & $\begin{array}{l}0.31^{* * *} \\
(0.12)\end{array}$ & $\begin{array}{r}0.09 \\
(0.13)\end{array}$ & $\begin{array}{c}--0.32 * * * \\
(0.10)\end{array}$ & $\begin{array}{c}--0.32^{* * *} \\
(0.08)\end{array}$ & $\begin{array}{l}--0.02 \\
(0.14)\end{array}$ & $\begin{array}{l}--0.16 \\
(0.13)\end{array}$ \\
\hline Household with a family enterprise & $\begin{array}{l}1.11^{* * *} \\
(0.12)\end{array}$ & $\begin{array}{l}1.48^{* * *} \\
(0.16)\end{array}$ & $\begin{array}{l}0.45^{* * *} \\
(0.13)\end{array}$ & $\begin{array}{l}0.59 * * * \\
(0.15)\end{array}$ & $\begin{array}{l}1.20 * * * \\
(0.10)\end{array}$ & $\begin{array}{l}1.60^{* * *} \\
(0.10)\end{array}$ & $\begin{array}{l}0.49 * * * \\
(0.14)\end{array}$ & $\begin{array}{l}0.32 * * \\
(0.15)\end{array}$ \\
\hline Living in a urban area & $\begin{array}{c}--0.53^{* * *} \\
(0.16)\end{array}$ & $\begin{array}{l}--0.22 \\
(0.18)\end{array}$ & $\begin{array}{l}0.31^{* *} \\
(0.15)\end{array}$ & $\begin{array}{l}0.52 * * * \\
(0.13)\end{array}$ & $\begin{array}{l}0.57^{* * *} \\
(0.11)\end{array}$ & $\begin{array}{l}0.74 * * * \\
(0.08)\end{array}$ & $\begin{array}{l}0.26^{* *} \\
(0.13)\end{array}$ & $\begin{array}{c}0.25 * \\
(0.13)\end{array}$ \\
\hline Non-labor income & $\begin{array}{c}--0.02 * * \\
(0.01)\end{array}$ & $\begin{array}{l}--0.04 \\
(0.02)\end{array}$ & $\begin{array}{l}--0.01^{*} \\
(0.00)\end{array}$ & $\begin{array}{c}--0.01^{* *} \\
(0.01)\end{array}$ & $\begin{array}{c}--0.00 * \\
(0.00)\end{array}$ & $\begin{array}{c}--0.01 * * \\
(0.01)\end{array}$ & $\begin{array}{l}--0.00 \\
(0.00)\end{array}$ & $\begin{array}{c}--0.01^{*} \\
(0.01)\end{array}$ \\
\hline Region2 (Pacific) & $\begin{array}{l}0.54^{* *} \\
(0.22)\end{array}$ & $\begin{array}{l}0.59 * * \\
(0.29)\end{array}$ & $\begin{array}{l}--0.20 \\
(0.12)\end{array}$ & $\begin{array}{c}--0.29 * * * \\
(0.11)\end{array}$ & $\begin{array}{r}0.15 \\
(0.11)\end{array}$ & $\begin{array}{l}0.20 * * \\
(0.09)\end{array}$ & $\begin{array}{r}0.13 \\
(0.12)\end{array}$ & $\begin{array}{l}--0.06 \\
(0.16)\end{array}$ \\
\hline Region3 (Central) & $\begin{array}{l}0.87^{* * *} \\
(0.20)\end{array}$ & $\begin{array}{l}0.49 * \\
(0.29)\end{array}$ & $\begin{array}{c}--0.39 * * * \\
(0.13)\end{array}$ & $\begin{array}{c}-0.54 * * * \\
(0.12)\end{array}$ & $\begin{array}{r}0.06 \\
(0.12)\end{array}$ & $\begin{array}{c}--0.17 * \\
(0.09)\end{array}$ & $\begin{array}{l}--0.04 \\
(0.15)\end{array}$ & $\begin{array}{c}--0.32 * \\
(0.18)\end{array}$ \\
\hline Region4 (Atlantic) & $\begin{array}{l}0.48^{* *} \\
(0.22)\end{array}$ & $\begin{array}{r}0.30 \\
(0.32)\end{array}$ & $\begin{array}{c}--0.67^{* * *} \\
(0.19)\end{array}$ & $\begin{array}{c}--0.35^{* *} \\
(0.16)\end{array}$ & $\begin{array}{l}--0.09 \\
(0.13)\end{array}$ & $\begin{array}{l}--0.19 \\
(0.12)\end{array}$ & $\begin{array}{l}--0.27 \\
(0.20)\end{array}$ & $\begin{array}{l}--0.28 \\
(0.21)\end{array}$ \\
\hline
\end{tabular}

Notes: The base outcome is "Inactive". *** indicates significance at $1 \%$ level, ** at $5 \%$ level; * at $10 \%$ level. Standard errors reported in parenthesis. 
Table 4: Participation to labor market equation (probit model).

\begin{tabular}{|c|c|c|}
\hline & \multicolumn{2}{|c|}{ Participation } \\
\hline & men & women \\
\hline Age & $\begin{array}{c}0.29 * * * \\
(0.01)\end{array}$ & $\begin{array}{c}0.17^{* * *} \\
(0.01)\end{array}$ \\
\hline Age squared/100 & $\begin{array}{c}--0.36 * * * \\
(0.01)\end{array}$ & $\begin{array}{c}--0.20 * * * \\
(0.01)\end{array}$ \\
\hline Incomplete primary & $\begin{array}{r}0.04 \\
(0.09)\end{array}$ & $\begin{array}{l}0.33^{* * *} \\
(0.09)\end{array}$ \\
\hline Primary/incomplete secondary & $\begin{array}{l}--0.05 \\
(0.09)\end{array}$ & $\begin{array}{l}0.52^{* * * *} \\
(0.08)\end{array}$ \\
\hline Secondary/tertiary & $\begin{array}{l}--0.18 \\
(0.13)\end{array}$ & $\begin{array}{l}1.04^{* * *} \\
(0.11)\end{array}$ \\
\hline Presence of a child in the household & $\begin{array}{l}0.22 * * * \\
(0.07)\end{array}$ & $\begin{array}{c}--0.13^{* *} \\
(0.05)\end{array}$ \\
\hline A member of the household in the formal sector & $\begin{array}{c}--0.16^{* *} \\
(0.06)\end{array}$ & $\begin{array}{c}--0.16^{* * * *} \\
(0.06)\end{array}$ \\
\hline Household with a family enterprise & $\begin{array}{l}0.84 * * * \\
(0.07)\end{array}$ & $\begin{array}{l}1.06^{* * *} \\
(0.07)\end{array}$ \\
\hline Living in a urban area & $\begin{array}{r}0.08 \\
(0.06)\end{array}$ & $\begin{array}{l}0.44^{* * *} \\
(0.06)\end{array}$ \\
\hline Non-labor income & $\begin{array}{l}--0.00 \\
(0.00)\end{array}$ & $\begin{array}{c}--0.01^{* *} \\
(0.00)\end{array}$ \\
\hline Region2 (Pacific) & $\begin{array}{r}0.07 \\
(0.07)\end{array}$ & $\begin{array}{r}0.07 \\
(0.06)\end{array}$ \\
\hline Region3 (Central) & $\begin{array}{c}0.14^{*} \\
(0.08)\end{array}$ & $\begin{array}{c}--0.18 * * * \\
(0.06)\end{array}$ \\
\hline Region4 (Atlantic) & $\begin{array}{l}--0.08 \\
(0.09)\end{array}$ & $\begin{array}{c}--0.17^{* *} \\
(0.08) \\
\end{array}$ \\
\hline
\end{tabular}

Notes: ${ }^{* * *}$ indicates significance at $1 \%$ level, ${ }^{* *}$ at $5 \%$ level; $*$ at $10 \%$ level. Standard errors reported in parenthesis. 
Table 5: Sector choice (multinomial probit model with sample selection).

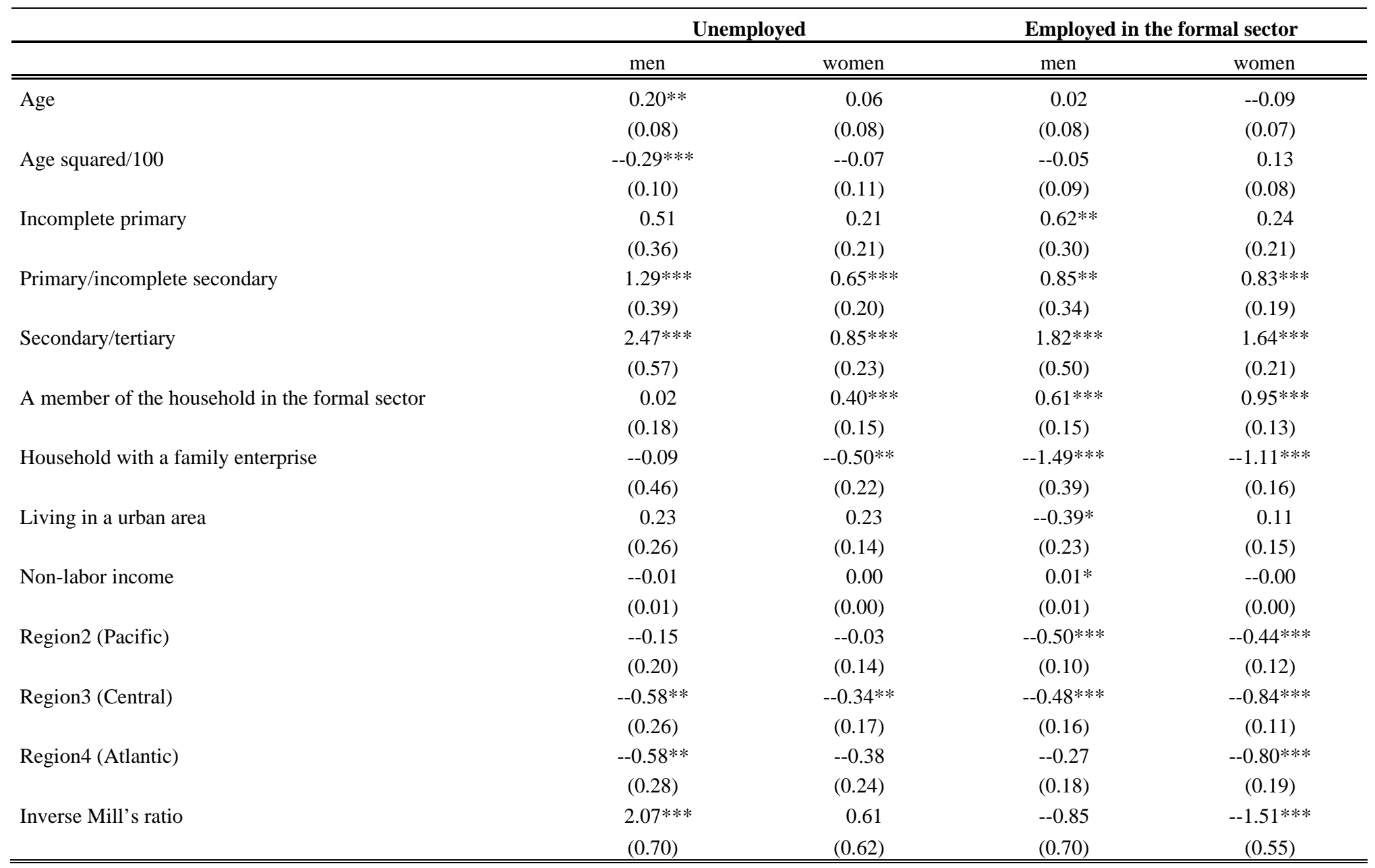

Notes: The base outcome is "Employed in the informal sector". *** indicates significance at 1\% level, ** at 5\% level; * at 10\% level. Standard errors reported in parenthesis. 
Table 6: Sector choice with agriculture (multinomial probit model with sample selection).

\begin{tabular}{|c|c|c|c|c|c|c|}
\hline & \multicolumn{2}{|c|}{ Employed in agriculture } & \multicolumn{2}{|c|}{ Employed in the formal sector } & \multicolumn{2}{|c|}{ Unemployed } \\
\hline & men & women & men & women & men & women \\
\hline \multirow[t]{2}{*}{ Age } & --0.03 & $--0.23^{*}$ & --0.09 & --0.02 & 0.05 & $0.17 * *$ \\
\hline & $(0.04)$ & $(0.12)$ & $(0.07)$ & $(0.08)$ & $(0.08)$ & $(0.08)$ \\
\hline \multirow[t]{2}{*}{ Age squared/100 } & 0.03 & $0.26^{*}$ & 0.12 & --0.00 & --0.07 & $--0.25^{* * *}$ \\
\hline & $(0.05)$ & $(0.14)$ & $(0.08)$ & $(0.09)$ & $(0.10)$ & $(0.10)$ \\
\hline \multirow[t]{2}{*}{ Incomplete primary } & $--0.62 * * *$ & $--0.51^{*}$ & 0.00 & $0.53^{*}$ & --0.13 & 0.41 \\
\hline & $(0.13)$ & $(0.29)$ & $(0.23)$ & $(0.30)$ & $(0.21)$ & $(0.35)$ \\
\hline \multirow[t]{2}{*}{ Primary/incomplete secondary } & $--1.26 * * *$ & $--1.04 * *$ & $0.48 * *$ & $0.65^{*}$ & 0.09 & $1.09 * * *$ \\
\hline & $(0.14)$ & $(0.41)$ & $(0.22)$ & $(0.34)$ & $(0.19)$ & $(0.38)$ \\
\hline \multirow[t]{2}{*}{ Secondary/tertiary } & $--1.10 * * *$ & $--1.57^{*}$ & $1.25^{* * *}$ & $1.54 * * *$ & 0.27 & $2.21 * * *$ \\
\hline & $(0.25)$ & $(0.83)$ & $(0.24)$ & $(0.50)$ & $(0.22)$ & $(0.55)$ \\
\hline \multirow[t]{2}{*}{ A member of the household in the formal sector } & --0.30 & 0.20 & $0.77 * * *$ & $0.61 * * *$ & $0.26^{*}$ & 0.03 \\
\hline & $(0.19)$ & $(0.27)$ & $(0.13)$ & $(0.15)$ & $(0.15)$ & $(0.18)$ \\
\hline \multirow[t]{2}{*}{ Household with a family enterprise } & -0.19 & --1.12 & $--1.04 * * *$ & $--1.65 * * *$ & $--0.47^{* *}$ & --0.14 \\
\hline & $(0.16)$ & $(0.68)$ & $(0.16)$ & $(0.39)$ & $(0.21)$ & $(0.45)$ \\
\hline \multirow[t]{2}{*}{ Living in a urban area } & $--1.25 * * *$ & $--1.46 * * *$ & $--0.28 *$ & $--0.61 * *$ & $--0.28 * *$ & 0.03 \\
\hline & $(0.20)$ & $(0.36)$ & $(0.15)$ & $(0.24)$ & $(0.14)$ & $(0.25)$ \\
\hline \multirow[t]{2}{*}{ Non-labor income } & --0.02 & --0.04 & --0.00 & $0.01 * *$ & 0.00 & --0.01 \\
\hline & $(0.01)$ & $(0.03)$ & $(0.00)$ & $(0.01)$ & $(0.00)$ & $(0.01)$ \\
\hline \multirow[t]{2}{*}{ Region2 (Pacific) } & 0.40 & 0.32 & $--0.39 * * *$ & $--0.57 * * *$ & 0.04 & --0.17 \\
\hline & $(0.28)$ & $(0.34)$ & $(0.11)$ & $(0.11)$ & $(0.14)$ & $(0.20)$ \\
\hline \multirow[t]{2}{*}{ Region3 (Central) } & $0.89 * * *$ & $0.89 * *$ & $--0.52 * * *$ & $--0.45 * * *$ & --0.02 & $--0.51 * *$ \\
\hline & $(0.24)$ & $(0.39)$ & $(0.13)$ & $(0.16)$ & $(0.18)$ & $(0.26)$ \\
\hline \multirow[t]{2}{*}{ Region4 (Atlantic) } & $0.63 * *$ & 0.69 & $--0.59 * * *$ & --0.20 & --0.20 & $--0.52 *$ \\
\hline & $(0.26)$ & $(0.43)$ & $(0.17)$ & $(0.18)$ & $(0.23)$ & $(0.28)$ \\
\hline \multirow[t]{2}{*}{ Inverse Mill's ratio } & --0.26 & $--1.60^{*}$ & $--1.47 * * *$ & $--1.26^{*}$ & 0.60 & $1.86 * * *$ \\
\hline & $(0.33)$ & $(0.95)$ & $(0.54)$ & $(0.70)$ & $(0.60)$ & $(0.68)$ \\
\hline
\end{tabular}

Notes: The base outcome is "Employed in the informal sector". *** indicates significance at $1 \%$ level, ** at $5 \%$ level; * at $10 \%$ level. Standard errors reported in parenthesis. 
Table 7: Simulated probability of sector choice (women).

\begin{tabular}{|c|c|c|c|c|c|}
\hline & \multicolumn{5}{|c|}{ Labor Market Outcomes } \\
\hline & Inactive & Unemployed & $\begin{array}{l}\text { Employed in the formal } \\
\text { sector }\end{array}$ & $\begin{array}{l}\text { Employed in the } \\
\text { informal sector }\end{array}$ & Employed in agriculture \\
\hline \multicolumn{6}{|l|}{ The role of education: } \\
\hline $\begin{array}{l}\text { Type 1: woman who is } 30 \text { years old with low non-labor income and with no } \\
\text { education. }\end{array}$ & 0.678 & 0.019 & 0.013 & 0.288 & 0.019 \\
\hline Type 2: as type 1 but with incomplete primary education. & 0.410 & 0.018 & 0.162 & 0.408 & 0.012 \\
\hline Type 3: as type 1 but with primary/ incomplete secondary education. & 0.334 & 0.029 & 0.222 & 0.413 & 0.007 \\
\hline Type 4: as type 1 but with secondary/tertiary education. & 0.143 & 0.032 & 0.531 & 0.291 & 0.002 \\
\hline Type 5: as type 1 but 40 years old. & 0.012 & 0.008 & 0.524 & 0.455 & 0.003 \\
\hline Type 6: as type 2 but 40 years old. & 0.006 & 0.010 & 0.583 & 0.399 & 0.001 \\
\hline Type 7: as type 3 but 40 years old. & 0.000 & 0.005 & 0.817 & 0.176 & 0.000 \\
\hline Type 8: as type 4 but 40 years old & 0.094 & 0.028 & 0.198 & 0.679 & 0.019 \\
\hline Type 9: as type 1 but 50 years old. & 0.000 & 0.000 & 0.745 & 0.253 & 0.000 \\
\hline Type 10: as type 2 but 50 years old. & 0.000 & 0.000 & 0.790 & 0.208 & 0.000 \\
\hline Type 12: as type 3 but 50 years old. & 0.000 & 0.000 & 0.932 & 0.067 & 0.000 \\
\hline Type 11: as type 4 but 50 years old. & 0.000 & 0.006 & 0.441 & 0.551 & 0.002 \\
\hline \multicolumn{6}{|l|}{ The role of non-labor income: } \\
\hline $\begin{array}{l}\text { Type 1a: woman who is } 30 \text { years old with non-labor income in the first quartile } \\
\text { and with primary/incomplete secondary education. }\end{array}$ & 0.334 & 0.029 & 0.222 & 0.413 & 0.007 \\
\hline Type 2a: as type 1a but with non-labor income in the second quartile & 0.337 & 0.028 & 0.221 & 0.412 & 0.007 \\
\hline Type 3a: as type 1a but with non-labor income in the third quartile & 0.341 & 0.028 & 0.220 & 0.409 & 0.007 \\
\hline Type 4a: as type 1a but with non-labor income in the fourth quartile & 0.368 & 0.026 & 0.212 & 0.392 & 0.004 \\
\hline Type 5a: as type 1 a but 40 years old & 0.006 & 0.010 & 0.583 & 0.399 & 0.001 \\
\hline Type 6a: as type 2a but 40 years old & 0.006 & 0.010 & 0.583 & 0.398 & 0.001 \\
\hline Type 7a: as type 3a but 40 years old & 0.007 & 0.010 & 0.584 & 0.398 & 0.001 \\
\hline Type 8a: as type 4a but 40 years old & 0.008 & 0.010 & 0.585 & 0.395 & 0.000 \\
\hline Type 9a: as type 1a but 50 years old & 0.000 & 0.000 & 0.790 & 0.208 & 0.000 \\
\hline Type 10a: as type 2a but 50 years old & 0.000 & 0.000 & 0.790 & 0.208 & 0.000 \\
\hline Type 11a: as type 3a but 50 years old & 0.000 & 0.000 & 0.790 & 0.208 & 0.000 \\
\hline Type 12a: as type $4 a$ but 50 years old & 0.000 & 0.000 & 0.791 & 0.207 & 0.000 \\
\hline
\end{tabular}




\section{Table 7 (continuing).}

The role of the family enterprise:

Type 1c: woman living in a household, which runs a family enterprise, and who is 30 years old

Type 2c: as type 1c but who is 40 years old

Type 3c: as type $1 \mathrm{c}$ but who is 50 years old

0.210

The role of living in urban areas:

Type 1d: woman living in a urban area and who is 30 years old

Type 2d: as type $1 \mathrm{~d}$ but who is 40 years old

Type 3d: as type $1 \mathrm{~d}$ but who is 50 years old

The role of a household member working in the formal sector:

Type 1e: woman living in a household where at least one member is employed

in the formal sector and who is 30 years old

Type 2e: as type 1e but who is 40 years old

Type 3e: as type $1 \mathrm{e}$ but who is 50 years old

0.004

0.000

0.002

0.000

0.581

0.037

0.037

0.000

0.514
0.009

0.003

0.000

0.007

0.002

0.000

0.021

0.021

0.015

0.002
0.050

0.205

0.404

0.051

0.195

0.390

0.102

0.495

0.734
0.729

0.786

0.594

0.775

0.775

0.609

0.294

0.451

0.263

0.011

0.000

0.034

0.010

\subsection{0}

0.02

0.005 
Table 8: Simulated probability of sector choice (men).

\begin{tabular}{|c|c|c|c|c|c|}
\hline & \multicolumn{5}{|c|}{ Labor Market Outcomes } \\
\hline & Inactive & Unemployed & $\begin{array}{l}\text { Employed in the formal } \\
\text { sector }\end{array}$ & $\begin{array}{l}\text { Employed in the } \\
\text { informal sector }\end{array}$ & Employed in agriculture \\
\hline \multicolumn{6}{|l|}{ The role of education: } \\
\hline $\begin{array}{l}\text { Type 1: man who is } 30 \text { years old with low non-labor income and with no } \\
\text { education. }\end{array}$ & 0.033 & 0.023 & 0.080 & 0.862 & 0.453 \\
\hline Type 2: as type 1 but with incomplete primary education. & 0.028 & 0.039 & 0.190 & 0.740 & 0.166 \\
\hline Type 3: as type 1 but with primary/ incomplete secondary education. & 0.029 & 0.051 & 0.265 & 0.654 & 0.082 \\
\hline Type 4: as type 1 but with secondary/tertiary education. & 0.034 & 0.050 & 0.460 & 0.454 & 0.041 \\
\hline Type 5: as type 1 but 40 years old. & 0.000 & 0.004 & 0.140 & 0.855 & 0.437 \\
\hline Type 6: as type 2 but 40 years old. & 0.000 & 0.007 & 0.290 & 0.702 & 0.142 \\
\hline Type 7: as type 3 but 40 years old. & 0.000 & 0.009 & 0.384 & 0.605 & 0.065 \\
\hline Type 8: as type 4 but 40 years old & 0.000 & 0.008 & 0.599 & 0.392 & 0.028 \\
\hline Type 9: as type 1 but 50 years old. & 0.000 & 0.000 & 0.441 & 0.551 & 0.376 \\
\hline Type 10: as type 2 but 50 years old. & 0.000 & 0.000 & 0.386 & 0.612 & 0.103 \\
\hline Type 12: as type 3 but 50 years old. & 0.000 & 0.000 & 0.489 & 0.509 & 0.041 \\
\hline Type 11: as type 4 but 50 years old. & 0.000 & 0.000 & 0.698 & 0.301 & 0.015 \\
\hline \multicolumn{6}{|l|}{ The role of non-labor income: } \\
\hline $\begin{array}{l}\text { Type 1a: man who is } 30 \text { years old with non-labor income in the first quartile } \\
\text { and with primary/incomplete secondary education. }\end{array}$ & 0.029 & 0.051 & 0.265 & 0.654 & 0.082 \\
\hline Type 2a: as type 1a but with non-labor income in the second quartile & 0.029 & 0.051 & 0.264 & 0.654 & 0.080 \\
\hline Type 3a: as type 1a but with non-labor income in the third quartile & 0.029 & 0.051 & 0.263 & 0.654 & 0.078 \\
\hline Type 4a: as type 1a but with non-labor income in the fourth quartile & 0.031 & 0.054 & 0.255 & 0.657 & 0.064 \\
\hline Type 5a: as type $1 \mathrm{a}$ but 40 years old & 0.000 & 0.009 & 0.384 & 0.605 & 0.065 \\
\hline Type 6a: as type 2a but 40 years old & 0.000 & 0.009 & 0.384 & 0.606 & 0.064 \\
\hline Type 7a: as type 3a but 40 years old & 0.000 & 0.009 & 0.383 & 0.607 & 0.062 \\
\hline Type 8a: as type $4 \mathrm{a}$ but 40 years old & 0.000 & 0.010 & 0.375 & 0.613 & 0.051 \\
\hline Type 9a: as type 1a but 50 years old & 0.000 & 0.000 & 0.489 & 0.509 & 0.041 \\
\hline Type 10a: as type 2a but 50 years old & 0.000 & 0.000 & 0.488 & 0.510 & 0.041 \\
\hline Type 11a: as type 3a but 50 years old & 0.000 & 0.000 & 0.487 & 0.511 & 0.039 \\
\hline Type 12a: as type 4a but 50 years old & 0.000 & 0.001 & 0.479 & 0.518 & 0.032 \\
\hline
\end{tabular}


Table 8 (continuing).

\begin{tabular}{|c|c|c|c|c|c|}
\hline \multicolumn{6}{|l|}{ The role of the family enterprise: } \\
\hline $\begin{array}{l}\text { Type 1c: man living in a household, which runs a family enterprise, and who is } \\
30 \text { years old }\end{array}$ & 0.006 & 0.016 & 0.073 & 0.903 & 0.254 \\
\hline Type 2c: as type 1c but who is 40 years old & 0.000 & 0.002 & 0.121 & 0.876 & 0.232 \\
\hline Type 3c: as type $1 \mathrm{c}$ but who is 50 years old & 0.000 & 0.000 & 0.181 & 0.817 & 0.192 \\
\hline \multicolumn{6}{|l|}{ The role of living in urban areas: } \\
\hline Type 1d: man living in a urban area and who is 30 years old & 0.006 & 0.017 & 0.075 & 0.900 & 0.181 \\
\hline Type $2 \mathrm{~d}$ : as type $1 \mathrm{~d}$ but who is 40 years old & 0.000 & 0.002 & 0.125 & 0.871 & 0.163 \\
\hline Type 3d: as type $1 \mathrm{~d}$ but who is 50 years old & 0.000 & 0.000 & 0.187 & 0.812 & 0.132 \\
\hline \multicolumn{6}{|l|}{ The role of a household member working in the formal sector: } \\
\hline $\begin{array}{l}\text { Type 1e: man living in a household where at least one member is employed in } \\
\text { the formal sector and who is } 30 \text { years old }\end{array}$ & 0.042 & 0.044 & 0.272 & 0.640 & 0.145 \\
\hline Type 2e: as type 1e but who is 40 years old & 0.000 & 0.008 & 0.395 & 0.595 & 0.121 \\
\hline Type 3e: as type $1 \mathrm{e}$ but who is 50 years old & 0.000 & 0.000 & 0.500 & 0.498 & 0.080 \\
\hline
\end{tabular}

Type 3e: as type 1e but who is 50 years old

0.000

0.500

0.080 
Figure 1: Average estimated probabilities of each sector by age, women.

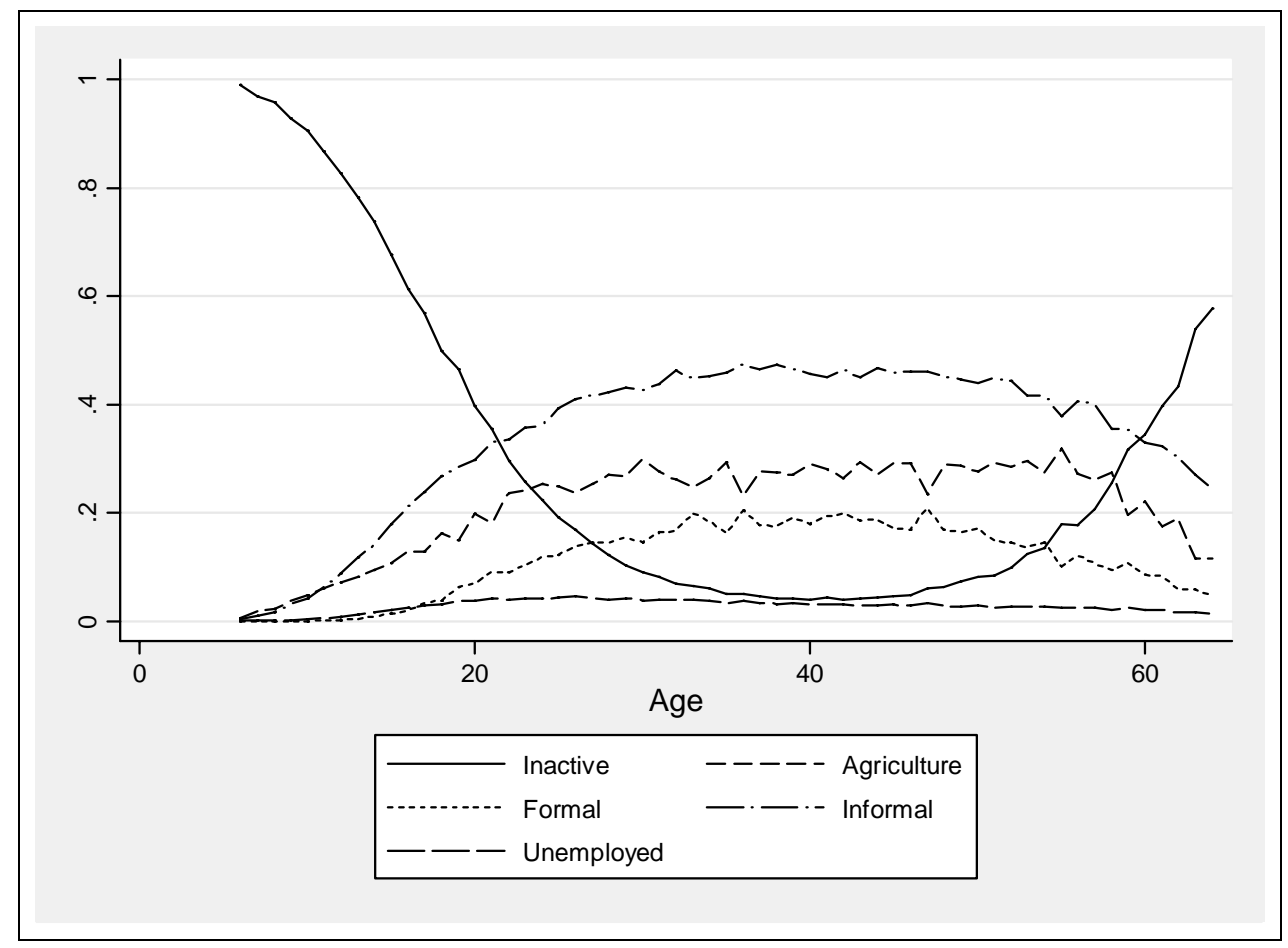


Figure 2: Average estimated probabilities of each sector by age, men.

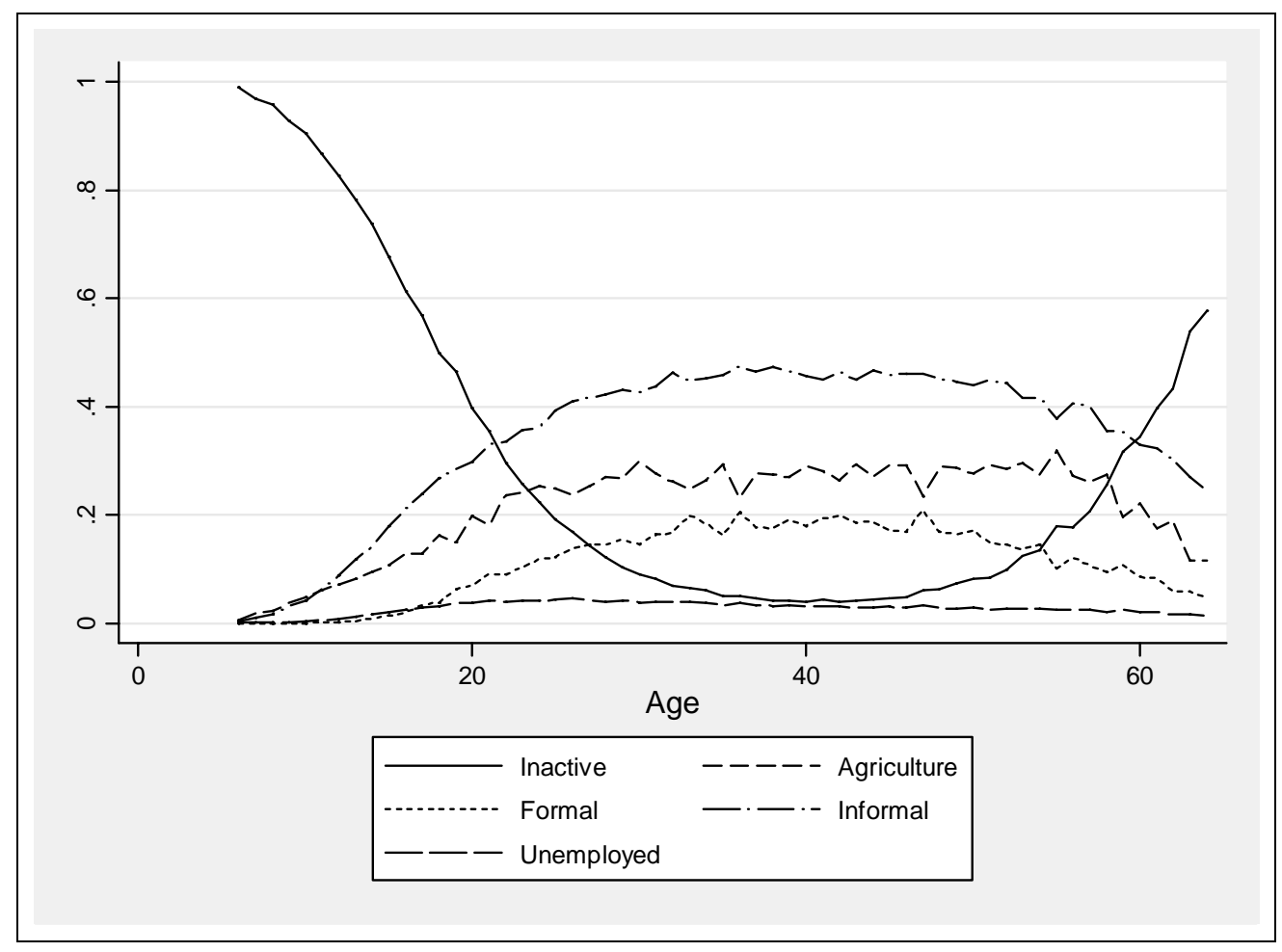


Department of Economics:

Skriftserie/Working Paper:

2003:

WP 03-1 Søren Harck: Er der nu en strukturelt bestemt langsigts-ledighed i SMEC?: Phillipskurven i SMEC 99 vis-à-vis SMEC 94. ISSN 1397-4831.

WP 03-2 Beatrice Schindler Rangvid: Evaluating Private School Quality in Denmark. ISSN 1397-4831.

WP 03-3 Tor Eriksson: Managerial Pay and Executive Turnover in the Czech and Slovak Republics. ISSN 1397-4831.

WP 03-4 Michael Svarer and Mette Verner: Do Children Stabilize Marriages? ISSN 1397-4831.

WP 03-5 Christian Bjørnskov and Gert Tinggaard Svendsen: Measuring social capital - Is there a single underlying explanation? ISSN 1397-4831.

WP 03-6 Vibeke Jakobsen and Nina Smith: The educational attainment of the children of the Danish 'guest worker' immigrants. ISSN 1397-4831.

WP 03-7 Anders Poulsen: The Survival and Welfare Implications of Altruism When Preferences are Endogenous. ISSN 1397-4831.

WP 03-8 Helena Skyt Nielsen and Mette Verner: Why are Well-educated Women not Full-timers? ISSN 1397-4831.

WP 03-9 Anders Poulsen: On Efficiency, Tie-Breaking Rules and Role Assignment Procedures in Evolutionary Bargaining. ISSN 13974831.

WP 03-10 Anders Poulsen and Gert Tinggaard Svendsen: Rise and Decline of Social Capital

- Excess Co-operation in the One-Shot Prisoner's Dilemma Game. ISSN 1397-4831. 
WP 03-11 Nabanita Datta Gupta and Amaresh Dubey: Poverty and Fertility: An Instrumental Variables Analysis on Indian Micro Data. ISSN 1397-4831.

WP 03-12 Tor Eriksson: The Managerial Power Impact on Compensation Some Further Evidence. ISSN 1397-4831.

WP 03-13 Christian Bjørnskov: Corruption and Social Capital. ISSN 13974831.

WP 03-14 Debashish Bhattacherjee: The Effects of Group Incentives in an Indian Firm

- Evidence from Payroll Data. ISSN 1397-4831.

WP 03-15 Tor Eriksson och Peter Jensen: Tidsbegränsade anställninger danska erfarenheter. ISSN 1397-4831.

WP 03-16 Tom Coupé, Valérie Smeets and Frédéric Warzynski: Incentives, Sorting and Productivity along the Career: Evidence from a Sample of Top Economists. ISSN 1397-4831.

WP 03-17 Jozef Koning, Patrick Van Cayseele and Frédéric Warzynski: The Effects of Privatization and Competitive Pressure on Firms' Price-Cost Margins: Micro Evidence from Emerging Economies. ISSN 1397-4831.

WP 03-18 Urs Steiner Brandt and Gert Tinggaard Svendsen: The coalition of industrialists and environmentalists in the climate change issue. ISSN 1397-4831.

WP 03-19 Jan Bentzen: An empirical analysis of gasoline price convergence for 20 OECD countries. ISSN 1397-4831.

WP 03-20 Jan Bentzen and Valdemar Smith: Regional income convergence in the Scandinavian countries. ISSN 1397-4831.

WP 03-21 Gert Tinggaard Svendsen: Social Capital, Corruption and Economic Growth: Eastern and Western Europe. ISSN 13974831.

WP 03-22 Jan Bentzen and Valdemar Smith: A Comparative Study of Wine Auction Prices: Mouton Rothschild Premier Cru Classé. ISSN 1397-4831. 
WP 03-23 Peter Guldager: Folkepensionisternes incitamenter til at arbejde. ISSN 1397-4831.

WP 03-24 Valérie Smeets and Frédéric Warzynski: Job Creation, Job Destruction and Voting Behavior in Poland. ISSN 1397-4831.

WP 03-25 Tom Coupé, Valérie Smeets and Frédéric Warzynski: Incentives in Economic Departments: Testing Tournaments? ISSN 13974831.

WP 03-26 Erik Strøjer Madsen, Valdemar Smith and Mogens DillingHansen: Industrial clusters, firm location and productivity Some empirical evidence for Danish firms. ISSN 1397-4831.

WP 03-27 Aycan Çelikaksoy, Helena Skyt Nielsen and Mette Verner: Marriage Migration: Just another case of positive assortative matching? ISSN 1397-4831.

2004:

WP 04-1 Elina Pylkkänen and Nina Smith: Career Interruptions due to Parental Leave - A Comparative Study of Denmark and Sweden. ISSN 1397-4831.

WP 04-2 Urs Steiner Brandt and Gert Tinggaard Svendsen: Switch Point and First-Mover Advantage: The Case of the Wind Turbine Industry. ISSN 1397-4831.

WP 04-3 Tor Eriksson and Jaime Ortega: The Adoption of Job Rotation: Testing the Theories. ISSN 1397-4831.

WP 04-4 Valérie Smeets: Are There Fast Tracks in Economic Departments? Evidence from a Sample of Top Economists. ISSN 1397-4831.

WP 04-5 Karsten Bjerring Olsen, Rikke Ibsen and Niels WestergaardNielsen: Does Outsourcing Create Unemployment? The Case of the Danish Textile and Clothing Industry. ISSN 1397-4831.

WP 04-6 Tor Eriksson and Johan Moritz Kuhn: Firm Spin-offs in Denmark 1981-2000 - Patterns of Entry and Exit. ISSN 13974831. 
WP 04-7 Mona Larsen and Nabanita Datta Gupta: The Impact of Health on Individual Retirement Plans: a Panel Analysis comparing Self-reported versus Diagnostic Measures. ISSN 1397-4831.

WP 04-8 Christian Bjørnskov: Inequality, Tolerance, and Growth. ISSN 1397-4831.

WP 04-9 Christian Bjørnskov: Legal Quality, Inequality, and Tolerance. ISSN 1397-4831.

WP 04-10 Karsten Bjerring Olsen: Economic Cooperation and Social Identity: Towards a Model of Economic Cross-Cultural Integration. ISSN 1397-4831.

WP 04-11 Iben Bolvig: Within- and between-firm mobility in the low-wage labour market. ISSN 1397-4831.

WP 04-12 Odile Poulsen and Gert Tinggaard Svendsen: Social Capital and Market Centralisation: A Two-Sector Model. ISSN 1397-4831.

WP 04-13 Aditya Goenka and Odile Poulsen: Factor Intensity Reversal and Ergodic Chaos. ISSN 1397-4831.

WP 04-14 Jan Bentzen and Valdemar Smith: Short-run and long-run relationships in the consumption of alcohol in the Scandinavian countries.

ISBN 87-7882-010-3 (print); ISBN 87-7882-011-1 (online).

WP 04-15 Jan Bentzen, Erik Strøjer Madsen, Valdemar Smith and Mogens Dilling-Hansen: Persistence in Corporate Performance? Empirical Evidence from Panel Unit Root Tests.

ISBN 87-7882-012-X (print); ISBN 87-7882-013-8 (online).

WP 04-16 Anders U. Poulsen and Jonathan H.W. Tan: Can Information Backfire? Experimental Evidence from the Ultimatum Game. ISBN 87-7882-014-6 (print); ISBN 87-7882-015-4 (online).

WP 04-17 Werner Roeger and Frédéric Warzynski: A Joint Estimation of Price-Cost Margins and Sunk Capital: Theory and Evidence from the European Electricity Industry.

ISBN 87-7882-016-2 (print); ISBN 87-7882-017-0 (online). 
WP 04-18 Nabanita Datta Gupta and Tor Eriksson: New workplace practices and the gender wage gap.

ISBN 87-7882-018-9 (print); ISBN 87-7882-019-7 (online).

WP 04-19 Tor Eriksson and Axel Werwatz: The Prevalence of Internal Labour Markets - New Evidence from Panel Data.

ISBN 87-7882-020-0 (print); ISBN 87-7882-021-9 (online).

WP 04-20 Anna Piil Damm and Michael Rosholm: Employment Effects of Dispersal Policies on Refugee Immigrants: Empirical Evidence. ISBN 87-7882-022-7 (print); ISBN 87-7882-023-5 (online).

2005:

WP 05-1 Anna Piil Damm and Michael Rosholm: Employment Effects of Dispersal Policies on Refugee Immigrants: Theory.

ISBN 87-7882-024-3 (print); ISBN 87-7882-025-1 (online).

WP 05-2 Anna Piil Damm: Immigrants’ Location Preferences: Exploiting a Natural Experiment.

ISBN 87-7882-036-7 (print); ISBN 87-7882-037-5 (online).

WP 05-3 Anna Piil Damm: The Danish Dispersal Policy on Refugee Immigrants 1986-1998: A Natural Experiment? ISBN 87-7882-038-3 (print); ISBN 87-7882-039-1 (online).

WP 05-4 Rikke Ibsen and Niels Westergaard-Nielsen: Job Creation and Destruction over the Business Cycles and the Impact on Individual Job Flows in Denmark 1980-2001.

ISBN 87-7882-040-5 (print); ISBN 87-7882-041-3 (online).

WP 05-5 Anna Maria Kossowska, Nina Smith, Valdemar Smith and Mette Verner: Til gavn for bundlinjen - Forbedrer kvinder i topledelse og bestyrelse danske virksomheders bundlinje?

ISBN 87-7882-042-1 (print); ISBN 87-7882-043-X (online).

WP 05-6 Odile Poulsen and Gert Tinggaard Svendsen: The Long and Winding Road: Social Capital and Commuting.

ISBN 87-7882-044-8 (print); ISBN 87-7882-045-6 (online).

WP 05-7 Odile Poulsen and Gert Tinggaard Svendsen: Love Thy Neighbor: Bonding versus Bridging Trust.

ISBN 87-7882-062-6 (print); ISBN 87-7882-063-4 (online). 
WP 05-8 Christian Bjørnskov: Political Ideology and Economic Freedom. ISBN 87-7882-064-2 (print); ISBN 87-7882-065-0 (online).

WP 05-9 Sebastian Buhai and Coen Teulings: Tenure Profiles and Efficient Separation in a Stochastic Productivity Model. ISBN 87-7882-066-9 (print); ISBN 87-7882-067-7 (online).

WP 05-10 Christian Grund and Niels Westergård-Nielsen: Age Structure of the Workforce and Firm Performance.

ISBN 87-7882-068-5 (print); ISBN 87-7882-069-3 (online).

WP 05-11 Søren Harck: AD-AS på dansk.

ISBN 87-7882-070-7 (print); ISBN 87-7882-071-5 (online).

WP 05-12 Søren Harck: Hviler Dansk Økonomi på en Cobb-Douglas teknologi?

ISBN 87-7882-092-8 (print); ISBN 87-7882-093-6 (online).

2006:

WP 06-1 Nicolai Kristensen and Edvard Johansson: New Evidence on Cross-Country Differences in Job Satisfaction Using Anchoring Vignettes.

ISBN 87-7882-094-4 (print); ISBN 87-7882-095-2 (online).

WP 06-2 Christian Bjørnskov: How Does Social Trust Affect Economic Growth?

ISBN 87-7882-096-0 (print); ISBN 87-7882-097-9 (online).

WP 06-3 Jan Bentzen, Erik Strøjer Madsen and Valdemar Smith: The Growth Opportunities for SMEs?

ISBN 87-7882-098-7 (print); ISBN 87-7882-099-5 (online).

WP 06-4 Anna Piil Damm: Ethnic Enclaves and Immigrant Labour Market Outcomes: Quasi-Experimental Evidence. ISBN 87-7882-100-2 (print); ISBN 87-7882-101-0 (online).

WP 06-5 Svend Jespersen, Nicolai Kristensen og Lars Skipper: En kritik af VEU-udvalgets arbejde.

ISBN 87-7882-159-2 (print); ISBN 87-7882-160-6 (online).

WP 06-6 Kræn Blume and Mette Verner: Welfare Dependency among Danish Immigrants.

ISBN 87-7882-161-4 (print); ISBN 87-7882-162-2 (online). 
WP 06-7 Jürgen Bitzer, Wolfram Schrettl and Philipp J.H. Schröder: Intrinsic Motivation versus Signaling in Open Source Software Development. ISBN 87-7882-163-0 (print); ISBN 87-7882-164-9 (online).

WP 06-8 Valérie Smeets, Kathryn Ierulli and Michael Gibbs: Mergers of Equals \& Unequals.

ISBN 87-7882-165-7 (print); ISBN 87-7882-166-5 (online).

WP 06-9 Valérie Smeets: Job Mobility and Wage Dynamics.

ISBN 87-7882-167-3 (print); ISBN 87-7882-168-1 (online).

WP 06-10 Valérie Smeets and Frédéric Warzynski: Testing Models of Hierarchy: Span of Control, Compensation and Career Dynamics.

ISBN 87-7882-187-8 (print); ISBN 87-7882-188-6 (online).

WP 06-11 Sebastian Buhai and Marco van der Leij: A Social Network Analysis of Occupational Segregation.

ISBN 87-7882-189-4 (print); ISBN 87-7882-190-8 (online).

2007:

WP 07-1 Christina Bjerg, Christian Bjørnskov and Anne Holm: Growth, Debt Burdens and Alleviating Effects of Foreign Aid in Least Developed Countries.

ISBN 87-7882-191-6 (print); ISBN 87-7882-192-4 (online).

WP 07-2 Jeremy T. Fox and Valérie Smeets: Do Input Quality and Structural Productivity Estimates Drive Measured Differences in Firm Productivity?

ISBN 87-7882-193-2 (print); ISBN 87-7882-194-0 (online).

WP 07-3 Elisabetta Trevisan: Job Security and New Restrictive Permanent Contracts. Are Spanish Workers More Worried of Losing Their Job?

ISBN 87-7882-195-9 (print); ISBN 87-7882-196-7 (online).

WP 07-4 Tor Eriksson and Jaime Ortega: Performance Pay and the "Time Squeeze”.

ISBN 9788778822079 (print); ISBN 9788778822086 (online). 
WP 07-5 Johan Moritz Kuhn: My Pay is Too Bad (I Quit). Your Pay is Too Good (You're Fired).

ISBN 9788778822093 (print); ISBN 9788778822109 (online).

WP 07-6 Christian Bjørnskov: Social trust and the growth of schooling. ISBN 9788778822116 (print); ISBN 9788778822123 (online).

WP 07-7 Jan Bentzen and Valdemar Smith: Explaining champagne prices in Scandinavia - what is the best predictor?

ISBN 9788778822130 (print); ISBN 9788778822147 (online).

WP 07-8 Sandra Cavaco, Jean-Michel Etienne and Ali Skalli: Identifying causal paths between health and socio-economic status:

Evidence from European older workforce surveys ISBN 9788778822154 (print); ISBN 9788778822161 (online).

WP 07-9 Søren Harck: Long-run properties of some Danish macroeconometric models: an analytical approach.

ISBN 9788778822390 (print); ISBN 9788778822406 (online).

WP 07-10 Takao Kato and Hideo Owan: Market Characteristics, Intra-Firm Coordination, and the Choice of Human Resource Management Systems: Evidence from New Japanese Data.

ISBN 9788778822413 (print); ISBN 9788778822420 (online).

WP 07-11 Astrid Würtz: The Long-Term Effect on Children of Increasing the Length of Parents' Birth-Related Leave.

ISBN 9788778822437 (print); ISBN 9788778822444 (online).

WP 07-12 Tor Eriksson and Marie-Claire Villeval: Performance Pay, Sorting and Social Motivation.

ISBN 9788778822451 (print); ISBN 9788778822468 (online).

WP 07-13 Jane Greve: Obesity and Labor Market Outcomes: New Danish Evidence.

ISBN 9788778822475 (print); ISBN 9788778822482 (online).

2008:

WP 08-1 Sebastian Buhai, Miguel Portela, Coen Teulings and Aico van Vuuren: Returns to Tenure or Seniority ISBN 9788778822826 (print); ISBN 9788778822833 (online). 
WP 08-2 Flora Bellone, Patrick Musso, Lionel Nesta et Frédéric Warzynski: L'effet pro-concurrentiel de l'intégration européenne : une analyse de l'évolution des taux de marge dans les industries manufacturières françaises ISBN 9788778822857 (print); ISBN 9788778822864 (online).

WP 08-3 Erdal Yalcin: The Proximity-Concentration Trade-Off under Goods Price and Exchange Rate Uncertainty ISBN 9788778822871 (print); ISBN 9788778822888 (online)

WP 08-4 Elke J. Jahn and Herbert Brücker: Migration and the Wage Curve: A Structural Approach to Measure the Wage and Employment Effects of Migration ISBN 9788778822895 (print); ISBN 9788778822901 (online)

WP 08-5 Søren Harck: A Phillips curve interpretation of error-correction models of the wage and price dynamics

ISBN 9788778822918 (print); ISBN 9788778822925 (online)

WP 08-6 Elke J. Jahn and Thomas Wagner: Job Security as an

Endogenous Job Characteristic

ISBN 9788778823182 (print); ISBN 9788778823199 (online)

WP 08-7 Jørgen Drud Hansen, Virmantas Kvedaras and Jørgen UlffMøller Nielsen: Monopolistic Competition, International Trade and Firm Heterogeneity - a Life Cycle Perspective ISBN 9788778823212 (print); ISBN 9788778823229 (online)

WP 08-8 Dario Pozzoli: The Transition to Work for Italian University Graduates ISBN 9788778823236 (print); ISBN 9788778823243 (online)

WP 08-9 Annalisa Cristini and Dario Pozzoli: New Workplace Practices and Firm Performance: a Comparative Study of Italy and Britain ISBN 9788778823250 (print); ISBN 9788778823267 (online)

WP 08-10 Paolo Buonanno and Dario Pozzoli: Early Labour Market Returns to College Subjects ISBN 9788778823274 (print); ISBN 9788778823281 (online)

WP 08-11 Iben Bolvig: Low wage after unemployment - the effect of changes in the UI system ISBN 9788778823441 (print); ISBN 9788778823458 (online) 
WP 08-12 Nina Smith, Valdemar Smith and Mette Verner: Women in Top Management and Firm Performance

ISBN 9788778823465 (print); ISBN 9788778823472 (online)

WP 08-13 Sebastian Buhai, Elena Cottini and Niels Westergård-Nielsen: The impact of workplace conditions on firm performance ISBN 9788778823496 (print); ISBN 9788778823502 (online)

WP 08-14 Michael Rosholm: Experimental Evidence on the Nature of the Danish Employment Miracle ISBN 9788778823526 (print); ISBN 9788778823533 (online)

WP 08-15 Christian Bjørnskov and Peter Kurrild-Klitgaard: Economic Growth and Institutional Reform in Modern Monarchies and Republics: A Historical Cross-Country Perspective 1820-2000 ISBN 9788778823540 (print); ISBN 9788778823557 (online)

WP 08-16 Nabanita Datta Gupta, Nicolai Kristensen and Dario Pozzoli: The Validity of Vignettes in Cross-Country Health Studies ISBN 9788778823694 (print); ISBN 9788778823700 (online)

WP 08-17 Anna Piil Damm and Marie Louise Schultz-Nielsen: The Construction of Neighbourhoods and its Relevance for the Measurement of Social and Ethnic Segregation: Evidence from Denmark ISBN 9788778823717 (print); ISBN 9788778823724 (online)

WP 08-18 Jørgen Drud Hansen and Jørgen Ulff-Møller Nielsen: Price as an Indicator for Quality in International Trade? ISBN 9788778823731 (print); ISBN 9788778823748 (online)

WP 08-19 Elke J. Jahn and John Wegner: Do Targeted Hiring Subsidies and Profiling Techniques Reduce Unemployment? ISBN 9788778823755 (print); ISBN 9788778823762 (online)

WP 08-20 Flora Bellone, Patrick Musso, Lionel Nesta and Frederic Warzynski: Endogenous Markups, Firm Productivity and International Trade: Testing Some Micro-Level Implications of the Melitz-Ottaviano Model ISBN 9788778823779 (print); ISBN 9788778823786 (online) 
WP 08-21 Linda Bell, Nina Smith, Valdemar Smith and Mette Verner: Gender differences in promotion into top-management jobs ISBN 9788778823830 (print); ISBN 9788778823847(online)

WP 08-22 Jan Bentzen and Valdemar Smith: An empirical analysis of the relationship between the consumption of alcohol and liver cirrhosis mortality ISBN 9788778823854 (print); ISBN 9788778823861(online)

WP 08-23 Gabriel J. Felbermayr, Sanne Hiller and Davide Sala: Does Immigration Boost Per Capita Income?

ISBN 9788778823878 (print); ISBN 9788778823885 (online)

WP 08-24 Christian Gormsen: Anti-Dumping with Heterogeneous Firms: New Protectionism for the New-New Trade Theory ISBN 9788778823892 (print); ISBN 9788778823908 (online)

WP 08-25 Andrew E. Clark, Nicolai Kristensen and Niels WestergårdNielsen: Economic Satisfaction and Income Rank in Small Neighbourhoods ISBN 9788778823915 (print); ISBN 9788778823922 (online)

WP 08-26 Erik Strøjer Madsen and Valdemar Smith: Commercialization of Innovations and Firm Performance ISBN 9788778823939 (print); ISBN 9788778823946 (online)

WP 08-27 Louise Lykke Brix and Jan Bentzen: Waste Generation In Denmark 1994-2005

An Environmental And Economic Analysis ISBN 9788778823953 (print); ISBN 9788778823977 (online)

WP 08-28 Ingo Geishecker, Jørgen Ulff-Møller Nielsen and Konrad Pawlik: How Important is Export-Platform FDI? Evidence from Multinational Activities in Poland ISBN 9788778823984 (print); ISBN 9788778823991 (online)

WP 08-29 Peder J. Pedersen and Mariola Pytlikova: EU Enlargement: Migration flows from Central and Eastern Europe into the Nordic countries - exploiting a natural experiment ISBN 9788778824004 (print); ISBN 9788778824028 (online) 
2009:

WP 09-1 Tomi Kyyrä, Pierpaolo Parrotta and Michael Rosholm: The Effect of Receiving Supplementary UI Benefits on Unemployment Duration ISBN 9788778824035 (print); ISBN 9788778824042 (online)

WP 09-2 Dario Pozzoli and Marco Ranzani: Old European Couples' Retirement Decisions: the Role of Love and Money ISBN 9788778824165 (print); ISBN 9788778824172 (online)

WP 09-3 Michael Gibbs, Mikel Tapia and Frederic Warzynski: Globalization, Superstars, and the Importance of Reputation: Theory \& Evidence from the Wine Industry ISBN 9788778824189 (print); ISBN 9788778824196 (online)

WP 09-4 Jan De Loecker and Frederic Warzynski: Markups and FirmLevel Export Status ISBN 9788778824202 (print); ISBN 9788778824219 (online)

WP 09-5 Tor Eriksson, Mariola Pytliková and Frédéric Warzynski: Increased Sorting and Wage Inequality in the Czech Republic: New Evidence Using Linked Employer-Employee Dataset ISBN 9788778824226 (print); ISBN 9788778824233 (online)

WP 09-6 Longhwa Chen and Tor Eriksson: Vacancy Duration, Wage Offers, and Job Requirements - Pre-Match Data Evidence ISBN 9788778824240 (print); ISBN 9788778824257 (online)

WP 09-7 Tor Eriksson, Valérie Smeets and Frédéric Warzynski: Small Open Economy Firms in International Trade: Evidence from Danish Transactions-Level Data ISBN 9788778823861 (print); ISBN 9788778823878 (online)

WP 09-8 Dario Pozzoli and Marco Ranzani: Participation and Sector Selection in Nicaragua ISBN 9788778823885 (print); ISBN 9788778823892 (online) 